\title{
Preparation of inclusion complexes composed of amylose and biodegradable poly(glycolic acid-co- $\varepsilon$-caprolactone) by vine-twining polymerization and their lipase-catalyzed hydrolysis behavior
}

\author{
Shintaro Nomura, Tsuyoshi Kyutoku, Naoyuki Shimomura, Yoshiro Kaneko and Jun-ichi Kadokawa \\ In this study, we found that amylose-poly(glycolic acid-co- $\varepsilon$-caprolactone) (P(GA-co-CL)) inclusion complexes were formed when \\ phosphorylase-catalyzed enzymatic polymerization was performed in the presence of biodegradable $P(G A-c o-C L) s$ according to a \\ vine-twining polymerization process. The X-ray diffraction patterns of the products showed the typical diffraction peaks due to \\ inclusion complexes composed of amylose and guest compounds. In addition, the ${ }^{1} \mathrm{H}$ NMR spectra of the products showed \\ the signals due to amylose and $\mathrm{P}(\mathrm{GA}-\mathrm{co}-\mathrm{CL})$, in spite of washing with good solvents for $\mathrm{P}(\mathrm{GA}-\mathrm{co}-\mathrm{CL})$, such as acetone and \\ chloroform. These results suggested that the products were inclusion complexes composed of amylose and $P(G A-c o-C L)$. The \\ compositional ratio of GA unit to $\mathrm{CL}$ unit in $\mathrm{P}(\mathrm{GA}-\mathrm{Co}-\mathrm{CL}) \mathrm{s}$ did not affect the inclusion behavior of amylose. On the other hand, \\ the results in the vine-twining polymerization using amorphous $\mathrm{P}(\mathrm{GA}-\mathrm{co}-\mathrm{CL}) \mathrm{s}$ and a crystalline poly(glycolic acid-block- $\varepsilon-$ \\ caprolactone) (P(GA-b-CL)) as guest polymers indicated that the crystallinity of the guest copolymers strongly affected the \\ formation of inclusion complexes with amylose. In addition, we found that lipase-catalyzed hydrolysis of $P(G A-c o-C L)$ in the \\ inclusion complex was partly inhibited, probably because amylose, which surrounded $\mathrm{P}(\mathrm{GA}-\mathrm{co}-\mathrm{CL})$, prevented the approach \\ of lipase.
}

Polymer Journal (2011) 43, 971-977; doi:10.1038/pj.2011.96; published online 28 September 2011

Keywords: amylose; biodegradable polymer; inclusion complex; phosphorylase; vine-twining polymerization

\section{INTRODUCTION}

Amylose, a natural linear polysaccharide with helical conformation linked through $(1 \rightarrow 4)$ - $\alpha$-glycosidic linkages, is a well-known host compound that forms inclusion complexes with various low-molecular-weight compounds, mainly by hydrophobic interactions between the guest molecules and the cavity of amylose. ${ }^{1-7}$ However, only limited research has been reported regarding the formation of inclusion complexes between amylose and polymeric compounds. ${ }^{8-14}$ Amylose in solid-state constructs stabilized crystalline structures associated with the formation of double helixes. ${ }^{15}$ In addition, single-stranded amylose in an aqueous solution gradually forms a double helix, resulting in a water-insoluble product. The stable double helix conformation of amylose is probably a significant reason for the difficulty in incorporating the long chains of polymeric compounds into the cavity of amylose by only hydrophobic interaction between amylose and the guest polymers.

Phosphorylase-catalyzed enzymatic polymerization using $\alpha$-D-glucose-1-phosphate (G-1-P) proceeds with the regio- and stereoselective construction of an $\alpha$-glycosidic bond under mild conditions, leading to the direct formation of amylose in aqueous media. ${ }^{16}$ This poly- merization is initiated from a maltooligosaccharide primer such as maltoheptaose $\left(\mathrm{G}_{7}\right)$. Then, the propagation proceeds through the following reversible reaction to produce a $(1 \rightarrow 4)$ - $\alpha$-glucan chain, that is, amylose: $[(\alpha, 1 \rightarrow 4)-\mathrm{G}]_{n}+\mathrm{G}-1-\mathrm{P} \leftrightarrows[(\alpha, 1 \rightarrow 4)-\mathrm{G}]_{n+1}+\mathrm{Pi}$. In the reaction, a glucose unit is transferred from G-1-P to the nonreducing $4-\mathrm{OH}$ terminus of a $(1 \rightarrow 4)-\alpha$-glucan chain, resulting in inorganic phosphate $(\mathrm{Pi})$.

By means of these enzymatic methods for direct construction of the polysaccharides, ${ }^{17-23}$ we have developed a new methodology for the preparation of inclusion complexes composed of amylose and synthetic polymers, ${ }^{24-35}$ which was achieved by the phosphorylase-catalyzed polymerization forming amylose in the presence of guest polymers. The representation of this reaction system is similar to the way that vines of plants grow twining around a rod. Accordingly, we have proposed the name 'vine-twining polymerization' to describe this polymerization method for the preparation of amylose-polymer inclusion complexes.

As the guest polymers for this polymerization system, hydrophobic polyethers, ${ }^{24,26}$ polyesters, ${ }^{25,27,32}$ poly(ester-ether) ${ }^{27}$ and polycarbonates ${ }^{31}$ have all been used to form corresponding inclusion complexes 
with amylose. From an environmental viewpoint, it is particularly interesting to prepare the amylose-polyester inclusion complexes because both the guest polyester, for example, poly( $\varepsilon$-caprolactone) (PCL) and the host amylose are biodegradable polymers.

In this paper, we describe an extensive study on the preparation of amylose-biodegradable polyester inclusion complexes by vine-twining polymerization using poly(glycolic acid-co- $\varepsilon$-caprolactone) (P(GA-co$\mathrm{CL})$ ) as a guest polyester; the guest polyester functions as a suture thread. Poly(glycolic acid) (PGA) has high crystallinity and low dispersibility in aqueous buffer for vine-twining polymerization, which probably results in the difficulty in incorporating PGA in the cavity of amylose. In this study, therefore, we used the copolyester, $\mathrm{P}(\mathrm{GA}-\mathrm{co}-\mathrm{CL})$, composed of the two biodegradable units as the guests, and we investigated vine-twining polymerization for various compositional ratios of glycolic acid (GA) unit to $\varepsilon$-caprolactone (CL) unit. In addition, the hydrolysis behavior of $\mathrm{P}(\mathrm{GA}-\mathrm{co}-\mathrm{CL}) \mathrm{s}$ in the amylose inclusion complexes by lipase was evaluated and compared with that of $\mathrm{P}(\mathrm{GA}-\mathrm{co}-\mathrm{CL})$ by itself. The control of the biodegradability in $\mathrm{P}(\mathrm{GA}-\mathrm{co}-\mathrm{CL})$ s through the inclusion of amylose will contribute to their further practical application in the future.

\section{EXPERIMENTAL PROCEDURE}

\section{Materials}

Thermostable phosphorylase from the thermophilic bacterium Aquifex aeolicus VF5 $\left(\sim 180 \mathrm{U} \mathrm{ml}^{-1}\right)$ was supplied by Ezaki Glico (Osaka, Japan). ${ }^{36}$ Lipase from the fungus Phycomyces nitens $\left(\sim 150 \mathrm{U} \mathrm{mg}^{-1}\right)$ was purchased from Wako Pure Chemical Industries (Osaka, Japan). P(GA-co-CL)s were prepared by copolymerization of GA and CL in a small amount of water with nitrogen flowing at $200{ }^{\circ} \mathrm{C}$ for $4 \mathrm{~h}$ according to a previously described procedure. ${ }^{37}$ Three $\mathrm{P}$ (GA-co$\mathrm{CL})$ with different compositional ratios of GA unit to CL unit of 0.61:1, 1.40:1 and 2.63:1 were prepared by copolymerization in the feed molar ratios of GA to CL of 1:1, 2:1 and 4:1, respectively. The compositional ratios were estimated by ${ }^{1} \mathrm{H}$ NMR measurements. The yields of these $\mathrm{P}(\mathrm{GA}-c o-\mathrm{CL}) \mathrm{s}$ were assessed to be $71 \%, 75 \%$ and $42 \%$, respectively. The number-average molecular weights $\left(M_{\mathrm{n}} \mathrm{s}\right)$ and the molecular weight distributions $\left(M_{\mathrm{w}} / M_{\mathrm{n}} \mathrm{s}\right)$ of these $\mathrm{P}(\mathrm{GA}-\mathrm{co}-\mathrm{CL}) \mathrm{s}$ were estimated by means of gel permeation chromatography. Poly(glycolic acid-block$\varepsilon$-caprolactone) $(\mathrm{P}(\mathrm{GA}-b-\mathrm{CL}))$ was prepared by ring-opening polymerization of glycolide in the presence of poly( $\varepsilon$-caprolactone) as a macroinitiator according to another procedure from the literature. ${ }^{38} \mathrm{G}_{7}$ was prepared by selective cleavage of one glycosidic bond of $\beta$-cyclodextrin under acidic conditions. ${ }^{39}$ All other reagents and solvents were used without further purification.

\section{A typical procedure for vine-twining polymerization using $\mathrm{P}(\mathrm{GA}-\mathrm{co}-\mathrm{CL})$ s as guests}

Sodium acetate buffer $\left(4.5 \mathrm{ml}, 0.2 \mathrm{moll}^{-1}, \mathrm{pH}=6.2\right)$ was added to a solution of $\mathrm{P}(\mathrm{GA}-\mathrm{co}-\mathrm{CL})\left(50 \mathrm{mg}, M_{\mathrm{n}}=1890\right.$, compositional ratio $\left.(\mathrm{GA}: \mathrm{CL})=0.61: 1\right)$ in acetone $(0.5 \mathrm{ml})$, followed by ultrasonication for a few seconds to obtain a suspension of $\mathrm{P}(\mathrm{GA}-\mathrm{co}-\mathrm{CL})$ (Run 1 in Table 1). After the addition of $\mathrm{G}_{7}$ $(3.1 \mathrm{mg}=2.7 \mu \mathrm{mol})$ and G-1-P disodium salt $(205.3 \mathrm{mg}=0.675 \mathrm{mmol})$ to the suspension, the $\mathrm{pH}$ was adjusted to a value of 6.2 using aqueous acetic acid $\left(0.2 \mathrm{moll}^{-1}\right.$; Table 1) Finally, phosphorylase $(50 \mu \mathrm{l}=9 \mathrm{U})$ was added to this suspension, and the mixture was stirred vigorously for $6 \mathrm{~h}$ at $40-45^{\circ} \mathrm{C}$. The precipitate was collected by filtration, washed with acetone, chloroform and water, and then dried under reduced pressure at room temperature to yield $20.4 \mathrm{mg}$ of the product (IC-0.61). This solid was analyzed using ${ }^{1} \mathrm{H}$ NMR ( $\left.400 \mathrm{MHz}, \mathrm{DMSO}-d_{6}\right)$ to yield the following results: $\delta=1.21-1.40$ (br, a), $\delta=1.45-1.65$ (br, b), $\delta=2.21-2.45$ (br, c), $\delta=3.15-3.81$ ( $\mathrm{m}, \mathbf{H}_{2}-\mathbf{H}_{\mathbf{6}}$ overlapping with HOD), $\delta=3.95-4.15$ (br, d), $\delta 4.48,5.33,5.40(\mathrm{OH}), \delta=4.60-4.95(\mathrm{br}, \mathbf{e})$ and $\delta=5.00-5.20\left(\mathrm{br}, \mathbf{H}_{1}\right)$.

The unit ratio of GA to CL in IC-0.61 was 0.62:1 (Run 1 in Table 1), and the length of the GA and CL units per one amylose helical turn $(0.80 \mathrm{~nm})$ was calculated to be $\sim 0.17 \mathrm{~nm}(0.62 \times 0.36 \times 0.80 /[0.62 \times 0.36+1 \times 0.84])$ and $0.63 \mathrm{~nm}(1 \times 0.84 \times 0.80 /[0.62 \times 0.36+1 \times 0.84])$, respectively. Therefore, the numbers of the methylene protons $\mathbf{e}$ of GA unit and $\mathbf{a}$ of CL unit in IC-0.61 were estimated to be $0.94(0.17 / 0.36 \times 2)$ and $1.50(0.63 / 0.84 \times 2)$, respectively. The calculated ratios of $\mathbf{e} / \mathbf{H}_{\mathbf{l}}$ and $\mathbf{a} / \mathbf{H}_{\mathbf{1}}$ in a helical turn were estimated to be $0.16(0.94 / 6)$ and $0.25(1.50 / 6)$, respectively, by dividing by the number of $\mathbf{H}_{1}$ in an amylose helical turn (6).

\section{Investigation of hydrolysis of $\mathrm{P}(\mathrm{GA}-\mathrm{co}-\mathrm{CL}) \mathrm{s}$ in the inclusion complex using lipase}

A standard experimental procedure was followed to investigate the hydrolysis behavior of the inclusion complexes. First, sodium acetate buffer $(1.0 \mathrm{ml}$, $\left.0.2 \mathrm{moll}^{-1}, \mathrm{pH}=6.2\right)$ was added to the inclusion complex (IC-1.40) $(5.0 \mathrm{mg}$, GA:CL in $\mathrm{P}(\mathrm{GA}-\mathrm{co}-\mathrm{CL})=1.05: 1$, with stirring to obtain a suspension. Subsequently, $150 \mathrm{U} \mathrm{ml}^{-1}$ of lipase solution in sodium acetate buffer $(50 \mu \mathrm{l}=7.5 \mathrm{U})$ was added to the resulting suspension, which was stirred at $40^{\circ} \mathrm{C}$ for $48 \mathrm{~h}$. After lyophilization of the suspension, the resulting powdered product was characterized by ${ }^{1} \mathrm{H}$ NMR measurements in DMSO- $d_{6}$ at $40{ }^{\circ} \mathrm{C}$.

\section{Measurements}

The ${ }^{1} \mathrm{H}$ NMR spectra were recorded using a JEOL ECX400 spectrometer (JEOL, Tokyo, Japan). The X-ray diffraction (XRD) measurements were performed at a scanning speed of $2 \theta=10.9^{\circ} \mathrm{min}^{-1}$ using an X'Pert Pro diffractometer (PANalytical, Almelo, the Netherlands) with Ni-filtered $\mathrm{Cu}$ $\mathrm{K} \alpha$ radiation $(\lambda=0.15418 \mathrm{~nm})$. The gel permeation chromatography analyses were performed using a HITACHI pump L-2130 and a HITACHI RI detector L-2490 (Hitachi, Tokyo, Japan), with Shodex GPC KF-804L and KF-803L columns (Showa Denko, Tokyo, Japan), and using chloroform as the eluent at a flow rate of $1.0 \mathrm{ml} \mathrm{min}^{-1}$ at $40^{\circ} \mathrm{C}$.

\section{RESULTS AND DISCUSSION}

Vine-twining polymerization using $\mathrm{P}(\mathrm{GA}-\mathrm{co}-\mathrm{CL})$ s with various compositional ratios of GA unit to $\mathrm{CL}$ unit

In our previous studies on the vine-twining polymerization, we obtained an inclusion complex using the biodegradable polymer

Table 1 Effect of compositional ratio of GA unit to $C L$ unit in $P(G A-c o-C L)$ on the formation of inclusion complexes in the vine-twining polymerization $^{\mathrm{a}}$

\begin{tabular}{|c|c|c|c|c|c|c|c|}
\hline \multirow[b]{2}{*}{ Run } & \multicolumn{2}{|c|}{ Used $P(G A-c o-C L)$} & \multirow{2}{*}{$\begin{array}{l}\text { GA:CL of } P(G A-C o-C L) \\
\text { Included in amylose }{ }^{b}\end{array}$} & \multicolumn{2}{|c|}{$e / H_{1}$ value } & \multicolumn{2}{|c|}{$\mathrm{a} / \mathrm{H}_{1}$ value } \\
\hline & $G A: C L^{\mathrm{b}}$ & $M_{n}\left(M_{w} / M_{n}\right)^{c}$ & & Theoretical & Actual $^{\mathrm{b}}$ & Theoretical & Actual $^{\mathrm{b}}$ \\
\hline 1 & $0.61: 1$ & $1890(1.83)$ & $0.62: 1$ & 0.16 & 0.18 & 0.25 & 0.28 \\
\hline 2 & $1.40: 1$ & $1580(1.91)$ & $1.05: 1$ & 0.23 & 0.22 & 0.22 & 0.21 \\
\hline 3 & $2.63: 1$ & $1510(1.62)$ & $2.31: 1$ & 0.37 & 0.39 & 0.16 & 0.17 \\
\hline
\end{tabular}

Abbreviations: $\mathrm{CL}$, caprolactone; $\mathrm{GA}$, glycolic acid; $\mathrm{M}_{\mathrm{n}}$, number-average molecular weight; $\mathrm{M}_{\mathrm{w}}$, molecular weight; $\mathrm{P}(\mathrm{GA}-\mathrm{co}-\mathrm{CL})$, poly(glycolic acid-co-e-caprolactone).

aPolymerization conditions: $\alpha$-D-glucose-1-phosphate (G-1-P), $0.675 \mathrm{mmol}=205.3 \mathrm{mg} ; \mathrm{G}_{7}, 2.7 \mu \mathrm{mol}=3.1 \mathrm{mg}$; phosphorylase, $9 \mathrm{U}=50 \mu \mathrm{l} ; \mathrm{P}(\mathrm{GA}-\mathrm{co}$-CL), $50 \mathrm{mg}$; solvent, acetone $(0.5 \mathrm{ml})+\mathrm{sodium}$

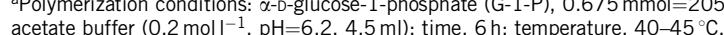

acetate buffer $\left(0.2 \mathrm{moll}^{-1}, \mathrm{pH}=6.2,4.5 \mathrm{~m}\right.$
${ }^{\mathrm{b}}$ Estimated by ${ }^{1} \mathrm{H}$ NMR measurements.

'Estimated by gel permeation chromatography measurements. 


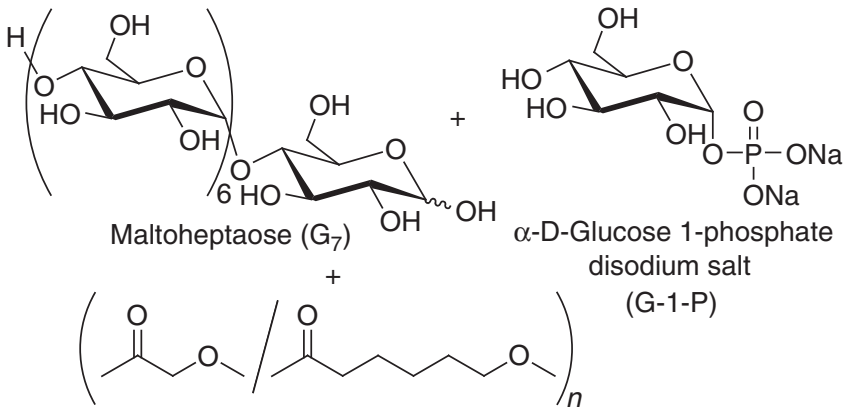

Poly(glycolic acid-co- $\varepsilon$-caprolactone) $\mathrm{P}(\mathrm{GA}-\mathrm{Co}-\mathrm{CL})$

$\left\{\begin{array}{l}\text { (a) } \mathrm{GA}: \mathrm{CL}=0.61: 1 \\ \text { (b) } \mathrm{GA}: \mathrm{CL}=1.40: 1\end{array}\right.$

(b) $\mathrm{GA}: C L=1.40: 1$
(c) $\mathrm{GA}: \mathrm{CL}=2.63: 1$

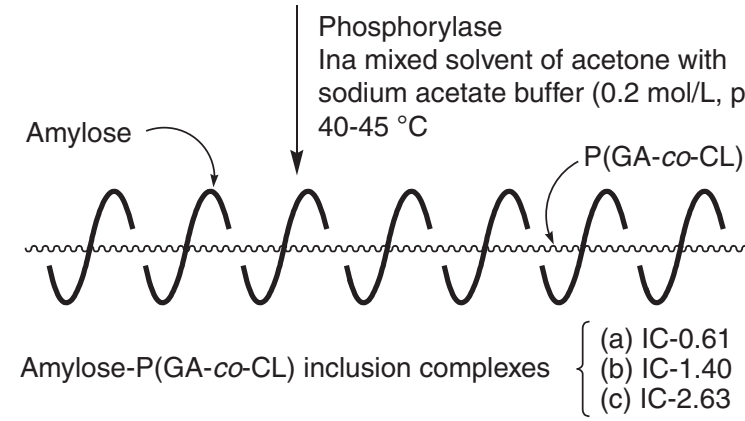

Scheme 1 Vine-twining polymerization using poly(glycolic acid-co- $\varepsilon^{-}$ caprolactone) (P(GA-co-CL))s as a guest.

PCL as a guest. ${ }^{25,27}$ However, when the vine-twining polymerization was preliminarily investigated using PGA as a guest in this study, the inclusion complex was not formed. This is probably due to aggregation of the PGA as a result of its high crystallinity that occurred in the aqueous buffer, which was used as a solvent for the enzymatic polymerization. On the basis of these previous and preliminary results, we concluded that the compositional ratio of GA unit to $\mathrm{CL}$ unit in $\mathrm{P}(\mathrm{GA}-\mathrm{co}-\mathrm{CL})$ s was an important factor in their incorporation by amylose through vine-twining polymerization. In this study, therefore, three $\mathrm{P}(\mathrm{GA}-\mathrm{co}-\mathrm{CL}) \mathrm{s}$ with different compositional ratios of GA unit to CL unit (specifically, 0.61:1, 1.40:1 and 2.63:1) were used as guests.

The vine-twining polymerization was first performed using $\mathrm{P}$ (GAco-CL) with a GA:CL ratio of $0.61: 1$ as a guest. This was achieved by the phosphorylase-catalyzed polymerization of G-1-P from $\mathrm{G}_{7}$ in the presence of the $\mathrm{P}(\mathrm{GA}-\mathrm{co}-\mathrm{CL})$ in a mixed solvent of acetone/sodium acetate buffer at $40{ }^{\circ} \mathrm{C}$ for $6 \mathrm{~h}$ (Scheme 1a). The precipitate was collected and characterized by means of XRD and ${ }^{1} \mathrm{H}$ NMR measurements.

The XRD pattern of the resulting product (IC-0.61) shows two diffraction peaks at $2 \theta=$ approximately $13^{\circ}$ and $20^{\circ}$ (Figure 1c), which is completely different from the XRD patterns of either amylose (Figure 1a) or $\mathrm{P}(\mathrm{GA}-\mathrm{co}-\mathrm{CL})$ (Figure $1 \mathrm{~b})$, but is similar to the patterns observed from the inclusion complexes of amylose with monomeric compounds $^{40,41}$ and with polymers. ${ }^{24-35}$ This result indicates that IC-0.61 is an inclusion complex composed of amylose and the guest $\mathrm{P}(\mathrm{GA}-\mathrm{co}-\mathrm{CL})$.

The ${ }^{1} \mathrm{H}$ NMR spectrum in DMSO- $d_{6}$ of IC-0.61 shows signals not only from amylose but also from $\mathrm{P}(\mathrm{GA}-\mathrm{co}-\mathrm{CL})$ (Figure 2), despite

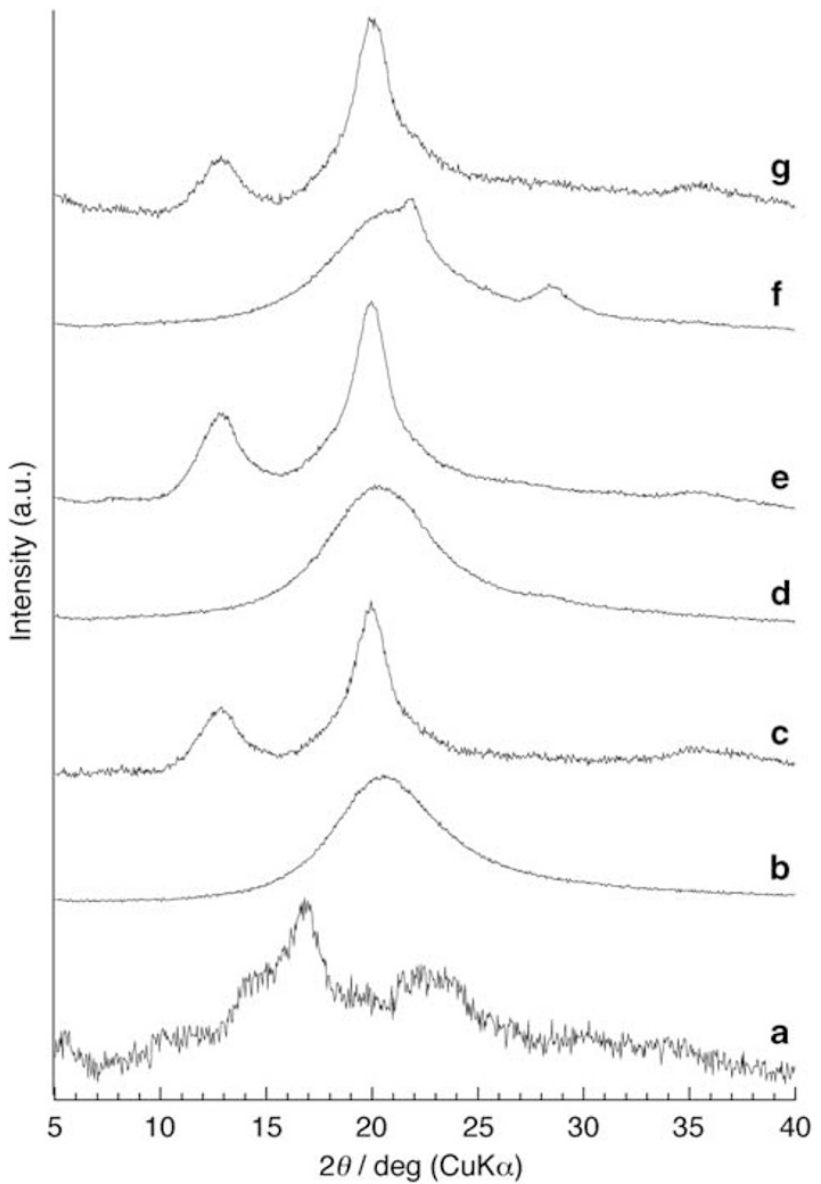

Figure 1 X-ray diffraction patterns of (a) amylose, (b) poly(glycolic acid-co- $\varepsilon$ caprolactone) $\mathrm{P}(\mathrm{GA}-\mathrm{co}-\mathrm{CL})(\mathrm{GA}: \mathrm{CL}=0.61: 1)$, (c) IC-0.61, (d) $\mathrm{P}(\mathrm{GA}-\mathrm{Co}-\mathrm{CL})$ (GA:CL=1.40:1), (e) IC-1.40, (f) $\mathrm{P}(\mathrm{GA}-\mathrm{Co}-\mathrm{CL}) \quad(\mathrm{GA}: \mathrm{CL}=2.63: 1) \quad$ and (g) IC2.63.

washing with both acetone and chloroform, which are good solvents for $\mathrm{P}(\mathrm{GA}-\mathrm{co}-\mathrm{CL})$. Generally, one helical turn of amylose is composed of $\sim 6$ repeating glucose units when linear molecules with a small cross-sectional area such as fatty acids are included (Figure 3). ${ }^{42-44}$ The repeat distance of the helix of amylose was reported as $\sim 0.80 \mathrm{~nm}$ (Figure 3), ${ }^{42-44}$ whereas the lengths of one GA unit and one CL unit in $\mathrm{P}(\mathrm{GA}-\mathrm{co}-\mathrm{CL})$ were calculated to be $\sim 0.36$ and $0.84 \mathrm{~nm}$, respectively, using the MM2 routine in the CS Chem 3D program package (Figure 3). On the basis of these values, theoretical ratios of the $\mathbf{H}_{\mathbf{1}}$ protons of amylose to the methylene protons $\mathbf{e}$ in $\mathrm{GA}$ unit $\left(\mathbf{e} / \mathbf{H}_{\mathbf{1}}\right)$ and to the methylene protons $\mathbf{a}$ in CL unit $\left(\mathbf{a} / \mathbf{H}_{1}\right)$ were calculated to be 0.16 and 0.25 , respectively, (Run 1 in Table 1 ; refer to the experimental section for a detailed calculation method). The actual integrated ratios of $\mathbf{e} / \mathbf{H}_{1}$ and $\mathbf{a} / \mathbf{H}_{1}$ in the ${ }^{1} \mathrm{H}$ NMR spectrum of IC-0.61 were 0.18 and 0.28 , respectively, which were in relative agreement with the aforementioned theoretical values (Run 1 in Table 1). The above ${ }^{1} \mathrm{H}$ NMR results also supported the conclusion that the product (IC-0.61) was the inclusion complex composed of amylose and $\mathrm{P}(\mathrm{GA}-\mathrm{co}-\mathrm{CL})$.

To investigate the effect of unit ratios of GA to CL in $\mathrm{P}(\mathrm{GA}-\mathrm{co}-\mathrm{CL}) \mathrm{s}$ as guests, we next performed the vine-twining polymerization using $\mathrm{P}(\mathrm{GA}-\mathrm{co}-\mathrm{CL})$ s with GA:CL ratios of 1.40:1 (Scheme $1 \mathrm{~b}$ ) and 2.63:1 (Scheme 1c). The XRD (Figures 1e,f) and ${ }^{1} \mathrm{H}$ NMR results of the products were the same as those of IC-0.61, suggesting the formation 
of an inclusion complex. In addition, the $\mathbf{e} / \mathbf{H}_{\mathbf{1}}$ and $\mathbf{a} / \mathbf{H}_{\mathbf{1}}$ values in the ${ }^{1} \mathrm{H}$ NMR spectra of IC- 1.40 were estimated to be 0.22 and 0.21 , and those values of IC-2.63 were assessed to be 0.39 and 0.17 , respectively, which were close to the theoretical values (Runs 2 and 3 in Table 1).

To understand the inclusion behavior of amylose toward these $\mathrm{P}(\mathrm{GA}-\mathrm{co}-\mathrm{CL}) \mathrm{s}$, the sequential pattern of GA unit and CL unit in the copolymer was estimated according to the following procedure. First, the monomer reactivity ratios $\left(r_{1}\right.$ and $\left.r_{2}\right)$, which are defined as the

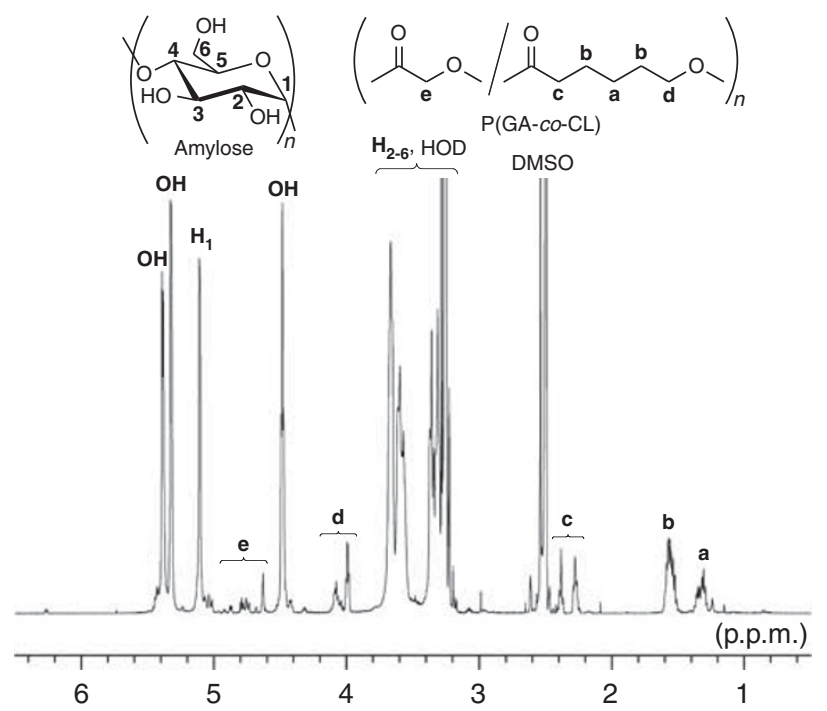

Figure $2{ }^{1} \mathrm{H}$ NMR spectrum in DMSO- $d_{6}$ of IC-0.61. ratios of kinetic constants $k_{(\mathrm{GA})(\mathrm{GA})} / k_{(\mathrm{GA})(\mathrm{CL})}$ and $k_{(\mathrm{CL})(\mathrm{CL})} / k_{(\mathrm{CL})(\mathrm{GA})}$, were calculated according to the Mayo-Lewis equation, ${ }^{45}$ to be 0.15 and 3.67, respectively. These values indicated that both the terminal GA unit and the terminal CL unit in the $\mathrm{P}(\mathrm{GA}-\mathrm{co}-\mathrm{CL})$ preferred to react with $\mathrm{CL}$ monomer rather than with GA monomer. Accordingly, the $\mathrm{P}(\mathrm{GA}-\mathrm{co}-\mathrm{CL}) \mathrm{s}$ with higher ratios of $\mathrm{CL}$ units were formed at an early stage of the copolymerization, and the residual GA monomer was polymerized at a later stage, resulting in the sequence distributions of GA unit and CL unit in the P(GA-co-CL)s. Consequently, segments containing a large number of GA units would be present in the random copolymer containing a higher compositional ratio of GA unit. As described previously, PGA did not form inclusion complexes with amylose by vine-twining polymerization, but the $\mathrm{P}(\mathrm{GA}-\mathrm{co}-\mathrm{CL})$ with higher compositional ratios of $\mathrm{GA}$ unit $(\mathrm{GA}: \mathrm{CL}=2.63: 1)$ did form inclusion complexes with amylose (Run 3 in Table 1), even though segments containing a large percentage of GA units would be present in this $\mathrm{P}(\mathrm{GA}-\mathrm{co}-\mathrm{CL})$, as determined by the monomer reactivity ratio calculations. We assume that the crystallinity of the $\mathrm{P}(\mathrm{GA}-\mathrm{co}-\mathrm{CL})$ is an important factor for the formation of inclusion complexes because the XRD profile of this $\mathrm{P}(\mathrm{GA}-\mathrm{co}-\mathrm{CL})$ as a random copolymer rarely showed diffraction peaks due to crystalline PGA (Figure 1f), which are generally observed at 22.3 and $29.1^{\circ}$.

To further investigate the effect of the crystallinity of the guest copolymer on formation of the inclusion complex, we synthesized a block copolymer composed of GA and CL (P(GA- $b-\mathrm{CL})$ ) with a ratio of GA unit to CL unit (2.31:1) similar to that of the aforementioned random copolymer (GA:CL=2.63:1). The XRD profile of the resulting $\mathrm{P}(\mathrm{GA}-b$ - $\mathrm{CL})$ showed the diffraction peaks due to crystalline PGA (Figure $4 \mathrm{a})$. When vine-twining polymerization was performed using this block copolymer $\mathrm{P}(\mathrm{GA}-b-\mathrm{CL})$, the inclusion complex was not formed, which was confirmed by XRD measurements (Figure $4 \mathrm{~b}$ ). On
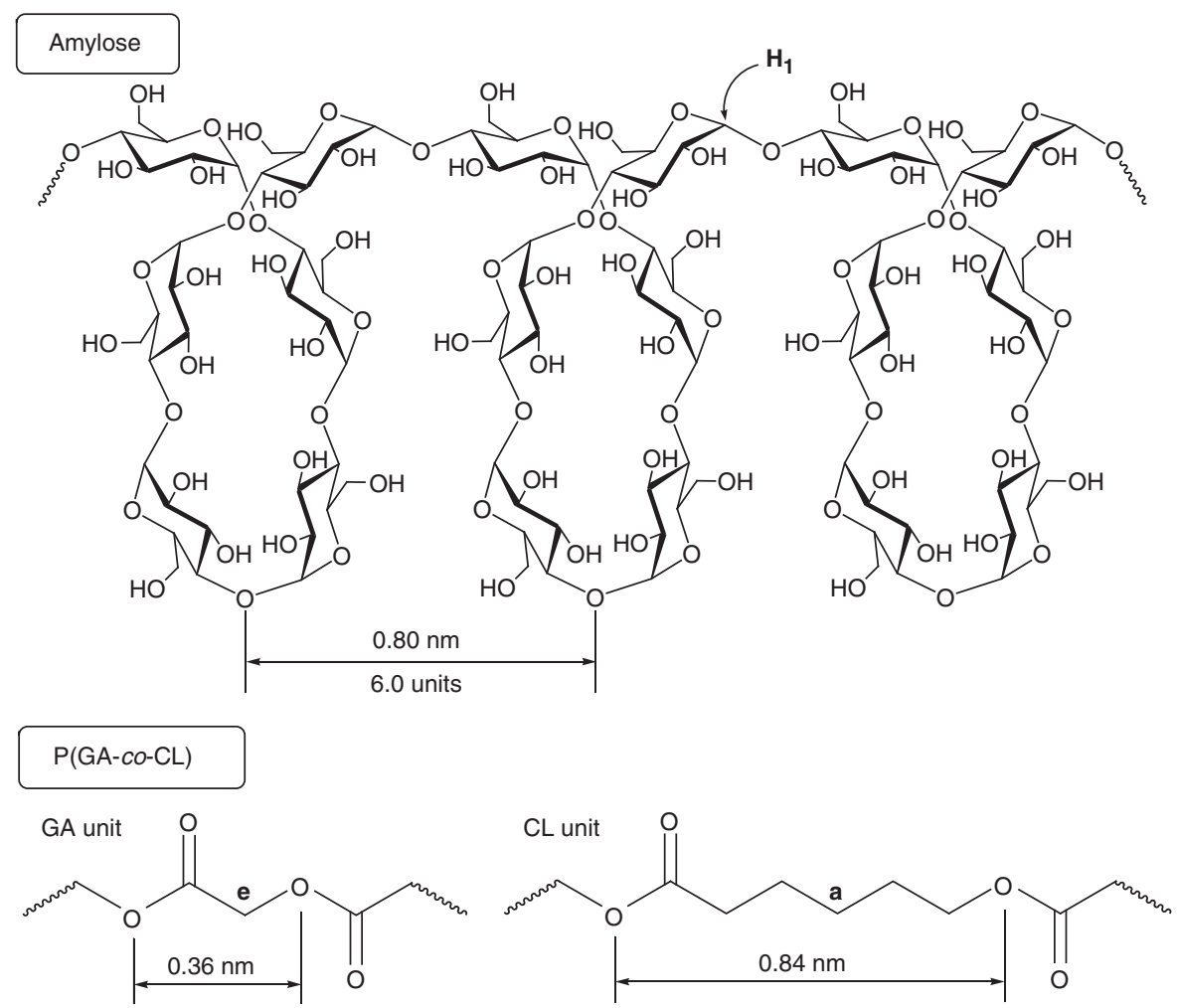

Figure 3 Illustration of the repeat distance of an amylose helix and the unit lengths of poly(glycolic acid-co- $\varepsilon$-caprolactone) (P(GA-co-CL)). 


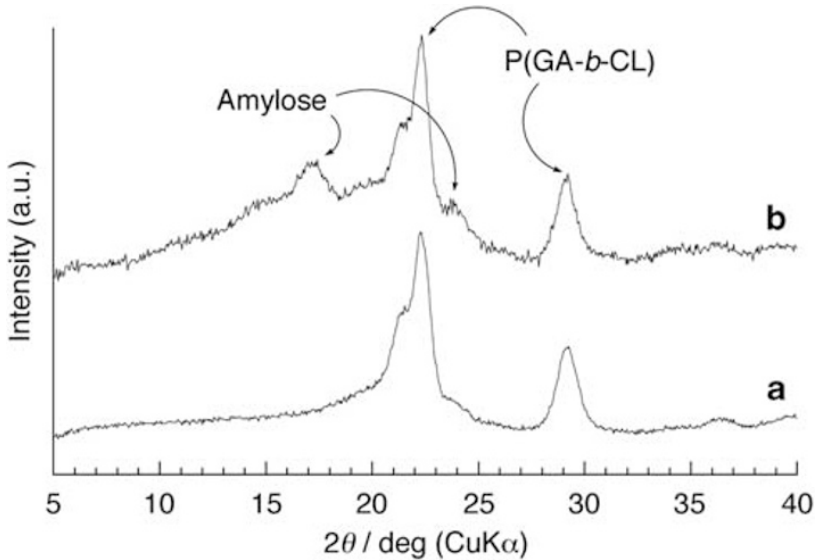

Figure 4 X-ray diffraction patterns of (a) poly(glycolic acid-block- caprolactone) $(\mathrm{P}(\mathrm{GA}-b-\mathrm{CL}))(\mathrm{GA}: \mathrm{CL}=2.31: 1)$ and $(\mathrm{b})$ the product obtained by vine-twining polymerization using the $\mathrm{P}(\mathrm{GA}-b-\mathrm{CL})$ as a guest.

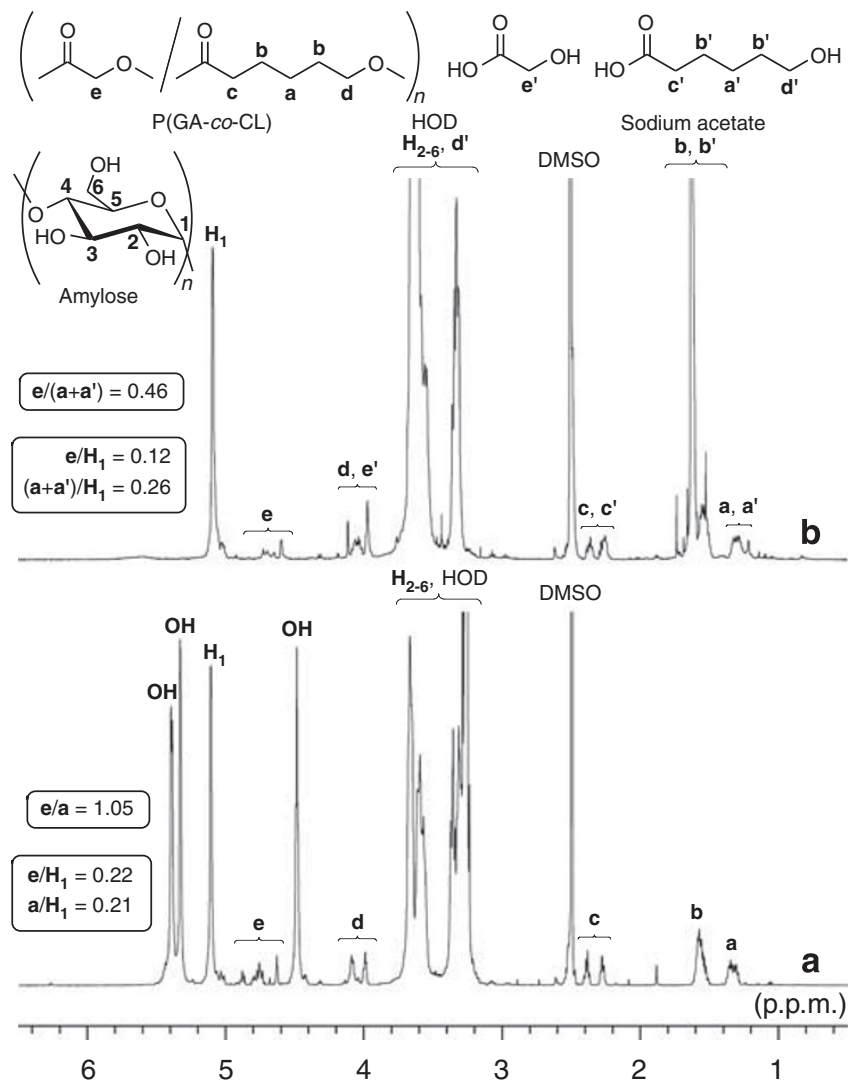

Figure $5{ }^{1} \mathrm{H}$ NMR spectra in DMSO- $d_{6}$ at $40^{\circ} \mathrm{C}$ of (a) IC-1.40 and (b) the product obtained by treatment of IC- 1.40 with lipase.

the basis of these results, we concluded that increased crystallinity of the guest reduced the likelihood of inclusion complex formation.

\section{Lipase-catalyzed hydrolysis behavior of $\mathrm{P}(\mathrm{GA}-\mathrm{co}-\mathrm{CL}) \mathrm{s}$ in the inclusion complexes}

Because $\mathrm{P}(\mathrm{GA}-\mathrm{co}-\mathrm{CL})$ is a biodegradable polymer, we investigated the hydrolysis behavior of $\mathrm{P}(\mathrm{GA}-\mathrm{co}-\mathrm{CL})$ in the inclusion complex IC-1.40 using lipase, which is an enzyme that catalyzes the hydrolysis of ester

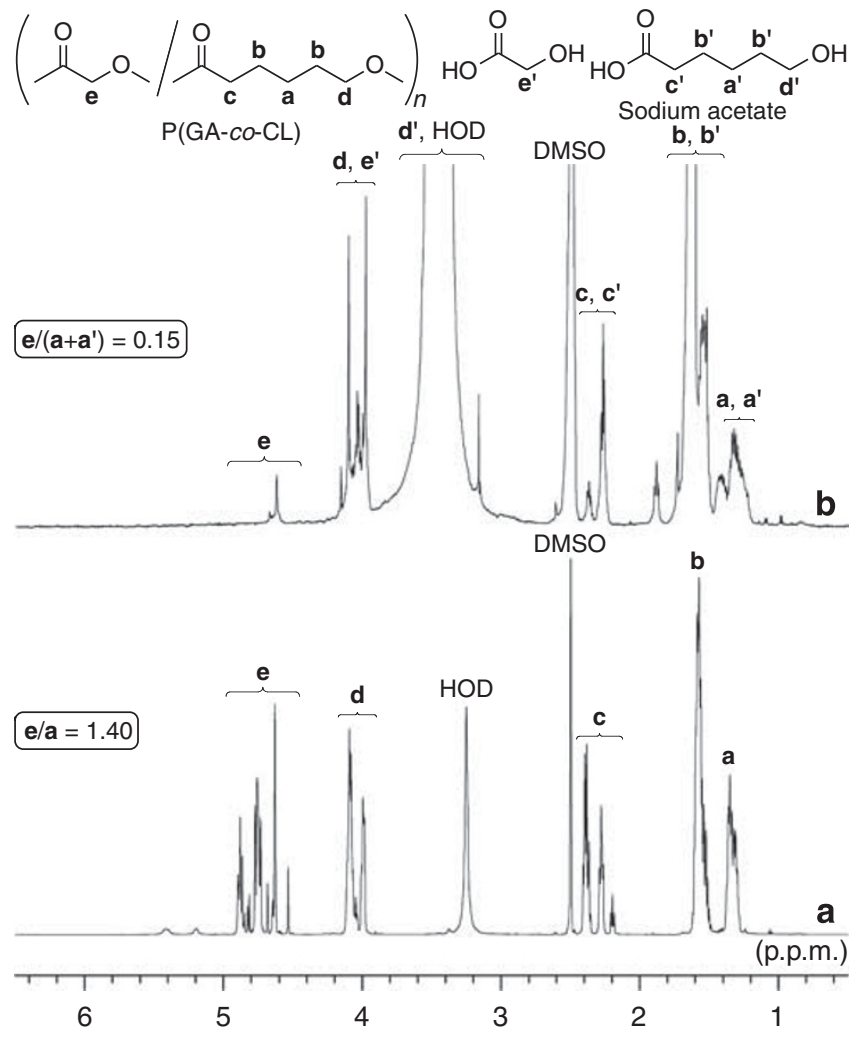

Figure $6{ }^{1} \mathrm{H}$ NMR spectra in DMSO- $d_{6}$ at $40^{\circ} \mathrm{C}$ of (a) poly(glycolic acid-co$\varepsilon$-caprolactone) (P(GA-co-CL)) $(\mathrm{GA}: \mathrm{CL}=1.40: 1)$ and (b) the product obtained by treatment of the $P(G A-C o-C L)$ with lipase.

linkages. ${ }^{46}$ Lipase was added to the suspension of the inclusion complex (Figure 5a, e/a ratio in $\mathrm{P}(\mathrm{GA}-\mathrm{co}-\mathrm{CL})=1.05$ ) in sodium acetate buffer, and the mixture was stirred at $40^{\circ} \mathrm{C}$ for $48 \mathrm{~h}$. In the ${ }^{1} \mathrm{H}$ NMR spectrum in DMSO- $d_{6}$ of the powdered product obtained by lyophilization of the resulting mixture, the integrated $\mathbf{e} /\left(\mathbf{a}+\mathbf{a}^{\prime}\right)$ ratio was calculated to be 0.46 (Figure $5 b$ ). Because the signals $\mathbf{a}$ and $\mathbf{a}^{\prime}$ are assigned to the methylene protons of $\mathrm{CL}$ units in $\mathrm{P}(\mathrm{GA}-\mathrm{co}-\mathrm{CL})$ and its hydrolysis product, respectively, whereas the signals $\mathbf{e}$ is ascribed to the methylene protons of GA units in $\mathrm{P}(\mathrm{GA}-c o-\mathrm{CL})$, the $\mathbf{e} /\left(\mathbf{a}+\mathbf{a}^{\prime}\right)$ value indicates a residual portion of $\mathrm{GA}$ unit in $\mathrm{P}(\mathrm{GA}-c o-\mathrm{CL})$ that is not hydrolyzed by lipase. Therefore, the hydrolysis ratio in the ester linkages of GA unit in $\mathrm{P}(\mathrm{GA}-\mathrm{co}-\mathrm{CL})$ was calculated to be $\sim 56 \%$ from the aforementioned $\mathbf{e} / \mathbf{a}$ value in the original $\mathrm{P}(\mathrm{GA}-\mathrm{co}-\mathrm{CL})$ and $\mathbf{e} /$ $\left(\mathbf{a}+\mathbf{a}^{\prime}\right)$ value in the products. Hydrolysis ratios in the ester linkages of GA units in $\mathrm{P}(\mathrm{GA}-\mathrm{co}-\mathrm{CL})$ s were calculated according to the following equation: hydrolysis ratio $=1-\left[\mathbf{e} /\left(\mathbf{a}+\mathbf{a}^{\prime}\right)\right] /[\mathbf{e} / \mathbf{a}]$. As a comparative experiment, the same operation using $\mathrm{P}(\mathrm{GA}-\mathrm{co}-\mathrm{CL})$ alone (Figure 6a, e/a ratio in $\mathrm{P}(\mathrm{GA}-c o-\mathrm{CL})=1.40$ ) was performed. Consequently, the integrated $\mathbf{e} /\left(\mathbf{a}+\mathbf{a}^{\prime}\right)$ ratio of the ${ }^{1} \mathrm{H}$ NMR spectrum in DMSO- $d_{6}$ of the resulting product was estimated to be 0.15 (Figure 6b), indicating that the hydrolysis ratio of GA units was $\sim 89 \%$, which was higher than that in the inclusion complex. These results indicate that lipase-catalyzed hydrolysis of GA unit of P(GA-co$\mathrm{CL}$ ) in the inclusion complex was partly inhibited, probably because amylose, that surrounded $\mathrm{P}(\mathrm{GA}-\mathrm{co}-\mathrm{CL})$, prevented the approach of lipase.

To further investigate the hydrolysis behaviors, the time-dependent changes in the hydrolysis ratio of GA unit of $\mathrm{P}(\mathrm{GA}-\mathrm{co}-\mathrm{CL})$ in the 


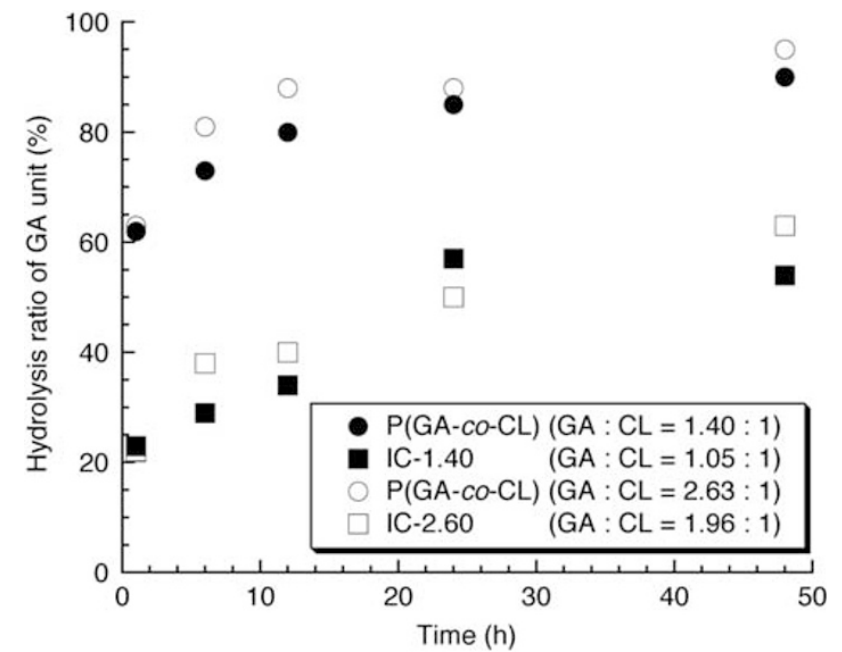

Figure 7 Time courses for the hydrolysis ratios of glycolic acid (GA) units of poly(glycolic acid-co-e-caprolactone) (P(GA-co-CL))s in the inclusion complexes and for $\mathrm{P}(\mathrm{GA}-\mathrm{Co}-\mathrm{CL}) \mathrm{s}$ alone.

inclusion complex IC-1.40 (GA:CL=1.05:1) were compared with those for $\mathrm{P}(\mathrm{GA}-c o-\mathrm{CL})$ alone (GA:CL=1.40:1; Figure 7). Accordingly, it was found that the hydrolysis behavior of the GA unit of $\mathrm{P}(\mathrm{GA}-\mathrm{co}$ $\mathrm{CL}$ ) alone reached a plateau within $\sim 12 \mathrm{~h}$, while the corresponding behavior of $\mathrm{P}(\mathrm{GA}-\mathrm{co}-\mathrm{CL}) \mathrm{s}$ in the inclusion complex took $\sim 24 \mathrm{~h}$ to reach a plateau. After the solutions reached a plateau, furthermore, the presence of enzymatic activity was confirmed by observing that when $\mathrm{P}(\mathrm{GA}-\mathrm{co}$-CL)s were added to both the samples after the lipasecatalyzed reactions for $48 \mathrm{~h}$ and the mixtures were additionally stirred for $24 \mathrm{~h}$, the GA units in the added $\mathrm{P}(\mathrm{GA}-\mathrm{co}-\mathrm{CL})$ s were hydrolyzed in both cases. The results in Figure 7, therefore, indicate that the GA unit of $\mathrm{P}(\mathrm{GA}-\mathrm{co}-\mathrm{CL}) \mathrm{s}$ in the inclusion complex was less hydrolyzed by lipase than was that of $\mathrm{P}(\mathrm{GA}-\mathrm{co}-\mathrm{CL})$ alone. In addition, when the time dependence of the hydrolysis ratio of the GA unit using IC-2.60 (GA:CL=1.96:1) and $\mathrm{P}(\mathrm{GA}-\mathrm{co}-\mathrm{CL})$ alone $(\mathrm{GA}: \mathrm{CL}=2.60: 1)$ was investigated, a similar trend as that described above was observed (Figure 7). This indicated that the compositional ratio of GA unit to CL unit did not affect the lipase-catalyzed hydrolysis behavior. However, the reason for the occurrence of hydrolysis for similar ratios of GA units of $\mathrm{P}(\mathrm{GA}-\mathrm{co}-\mathrm{CL}) \mathrm{s}$ in the inclusion complexes, regardless of the compositional ratios of GA unit to CL unit, is not yet clear.

\section{CONCLUSIONS}

In this paper, we described the preparation of inclusion complexes composed of amylose and biodegradable polyester $\mathrm{P}(\mathrm{GA}-\mathrm{co}-\mathrm{CL})$ through vine-twining polymerization. The compositional ratio of GA unit to CL unit in $\mathrm{P}(\mathrm{GA}-\mathrm{co}-\mathrm{CL})$ s did not affect the inclusion behavior of amylose. By comparing the results in the vine-twining polymerization using amorphous $\mathrm{P}(\mathrm{GA}-\mathrm{co}-\mathrm{CL}) \mathrm{s}$ and a crystalline $\mathrm{P}(\mathrm{GA}-b-\mathrm{CL})$ as guest polymers, it was found that the crystallinity of the guest copolymers strongly affected the formation of inclusion complexes with amylose. In addition, we found that the lipasecatalyzed hydrolysis of GA unit of $\mathrm{P}(\mathrm{GA}-\mathrm{co}-\mathrm{CL})$ in the inclusion complex was partially inhibited. This is probably because amylose, that surrounded $\mathrm{P}(\mathrm{GA}-\mathrm{co}-\mathrm{CL})$, prevented the approach of lipase.

\section{ACKNOWLEDGEMENTS}

We acknowledge the gift of phosphorylase from Ezaki Glico.
1 Kim, O. K., Choi, L. S., Zhang, H. Y., He, X. H. \& Shih, Y. H. Second-harmonic generation by spontaneous self-poling of supramolecular thin films of an amylose-dye inclusion complex. J. Am. Chem. Soc. 118, 12220-12221 (1996).

2 Choi, L. S. \& Kim, O. K. Unusual thermochromic behavior of photoreactive dyes confined in helical amylose as inclusion complex. Macromolecules 31, 9406-9408 (1998).

3 Sanji, T., Kato, N., Kato, M. \& Tanaka, M. Helical folding in a helical channel: chiroptical transcription of helical information through chiral wrapping. Angew. Chem. Int. Ed. 44, 7301-7304 (2005).

4 Lalush, I., Bar, H., Zakaria, I., Eichler, S. \& Shimoni, E. Utilization of amylose-lipid complexes as molecular nanocapsules for conjugated linoleic acid. Biomacromolecules 6, 121-130 (2005).

5 Sanji, T., Kato, N. \& Tanaka, M. Switching of optical activity in oligosilane through ph-responsive chiral wrapping with amylose. Macromolecules 39, 7508-7512 (2006).

6 Kim, O. K., Je, J. \& Melinger, J. S. One-dimensional energy/electron transfer through a helical channel. J. Am. Chem. Soc. 128, 4532-4533 (2006).

7 Sanji, T., Kato, N. \& Tanaka, M. Chirality control in oligothiophene through chiral wrapping. Org. Lett. 8, 235-238 (2006).

8 Shogren, R. L., Greene, R. V. \& Wu, Y. V. Complexes of starch polysaccharides and poly(ethylene-co-acrylic acid) - structure and stability in solution. J. Appl. Polym. Sci. 42, 1701-1709 (1991).

9 Shogren, R. L. Complexes of starch with telechelic poly( $\varepsilon$-caprolactone) phosphate. Carbohydr. Polym. 22, 93-98 (1993).

10 Ikeda, M., Furusho, Y., Okoshi, K., Tanahara, S., Maeda, K., Nishino, S., Mori, T. \& Yashima, E. A luminescent poly(phenylenevinylene)-amylose composite with supramolecular liquid crystallinity. Angew. Chem. Int. Ed. 45, 6491-6495 (2006).

11 Kida, T., Minabe, T., Okabe, S. \& Akashi, M. Partially-methylated amyloses as effective hosts for inclusion complex formation with polymeric guests. Chem. Commun. 1559-1561 (2007).

12 Kida, T., Minabe, T., Nakano, S. \& Akashi, M. Fabrication of novel multilayered thin films based on inclusion complex formation between amylose derivatives and guest polymers. Langmuir 24, 9227-9229 (2008).

13 Frampton, M. J., Claridge, T. D. W., Latini, G., Brovelli, S., Cacialli, F. \& Anderson, L. Amylose-wrapped luminescent conjugated polymers. Chem. Commun. 2797-2799 (2008).

14 Kaneko, Y., Kyutoku, T., Shimomura, N. \& Kadokawa, J. Formation of amylosepoly(tetrahydrofuran) inclusion complexes in ionic liquid media. Chem. Lett. 40, 31-33 (2011).

15 Hsein-Chih, H. W. \& Sarko, A. The double-helical molecular structure of crystalline $\beta$ amylose. Carbohydr. Res. 61, 7-25 (1978).

16 Ziegast, G. \& Pfannemüller, B. Phosphorolytic syntheses with di-, oligo- and multifunctional primers. Carbohydr. Res. 160, 185-204 (1987).

17 Kobayashi, S., Uyama, H. \& Kimura, S. Enzymatic polymerization. Chem. Rev. 101, 3793-3818 (2001).

18 Shoda, S., Izumi, R. \& Fujita, M. Green process in glycotechnology. Bull. Chem. Soc. Jpn. 76, 1-13 (2003).

19 Kobayashi, S., Ohmae, M., Fujikawa, S. \& Ochiai, H. Enzymatic precision polymerization for synthesis of glycosaminoglycans and their derivatives. Macromol. Symp. 226, 147-156 (2005).

20 Kobayashi, S. \& Ohmae, M. Enzymatic polymerization to polysaccharides. Adv. Polym. Sci. 194, 159-210 (2006).

21 Kobayashi, S. \& Makino, A. Enzymatic polymer synthesis: an opportunity for green polymer chemistry. Chem. Rev. 109, 5288-5353 (2009).

22 Kadokawa, J. \& Kobayashi, S. Polymer synthesis by enzymatic catalysis. Curr. Opin. Chem. Biol. 14, 145-153 (2010).

23 Kadokawa, J. Precision polysaccharide synthesis catalyzed by enzymes. Chem. Rev. 111, 4308-4345 (2011).

24 Kadokawa, J., Kaneko, Y., Tagaya, H. \& Chiba, K. Synthesis of an amylosepolymer inclusion complex by enzymatic polymerization of glucose 1-phosphate catalyzed by phosphorylase enzyme in the presence of polyTHF: a new method for synthesis of polymer-polymer inclusion complexes. Chem. Commun. 449-450 (2001).

25 Kadokawa, J., Kaneko, Y., Nakaya, A. \& Tagaya, H. Formation of an amylose-polyester inclusion complex by means of phosphorylase-catalyzed enzymatic polymerization of $\alpha$ D-glucose 1-phosphate monomer in the presence of poly( $\varepsilon$-caprolactone). Macromolecules 34, 6536-6538 (2001).

26 Kadokawa, J., Kaneko, Y., Nagase, S., Takahashi, T. \& Tagaya, H. Vine-twining polymerization: amylose twines around polyethers to form amylose-polyether inclusion complexes. Chem. Eur. J. 8, 3321-3326 (2002).

27 Kadokawa, J., Nakaya, A., Kaneko, Y. \& Tagaya, H. Preparation of inclusion complexes between amylose and ester-containing polymers by means of vine-twining polymerization. Macromol. Chem. Phys. 204, 1451-1457 (2003).

28 Kaneko, Y. \& Kadokawa, J. Vine-twining polymerization: a new preparation method for well-defined supramolecules composed of amylose and synthetic polymers. Chem. Rec. 5, 36-46 (2005).

29 Kaneko, Y. \& Kadokawa, J. Synthesis of nanostructured bio-related materials by hybridization of synthetic polymers with polysaccharides or saccharide residues. J. Biomater. Sci., Polymer Edn. 17, 1269-1284 (2006).

30 Kaneko, Y., Beppu, K. \& Kadokawa, J. Amylose selectively includes one from a mixture of two resemblant polyethers in vine-twining polymerization. Biomacromolecules $\mathbf{8}$, 2983-2985 (2007). 
31 Kaneko, Y., Beppu, K. \& Kadokawa, J. Preparation of amylose/polycarbonate inclusion complexes by means of vine-twining polymerization. Macromol. Chem. Phys. 209, 1037-1042 (2008)

32 Kaneko, Y., Saito, Y., Nakaya, A., Kadokawa, J. \& Tagaya, H. Preparation of inclusion complexes composed of amylose and strongly hydrophobic polyesters in parallel enzymatic polymerization system. Macromolecules 41, 5665-5670 (2008).

33 Kaneko, Y., Beppu, K., Kyutoku, T. \& Kadokawa, J. Selectivity and priority on inclusion of amylose toward guest polyethers and polyesters in vine-twining polymerization. Polym. J. 41, 279-286 (2009).

34 Kaneko, Y., Beppu, K. \& Kadokawa, J. Amylose selectively includes a specific range of molecular weights in poly(tetrahydrofuran)s in vine-twining polymerization. Polym. J. 41, 792-796 (2009).

35 Kaneko, Y., Fujisaki, K., Kyutoku, T., Furukawa, H. \& Kadokawa, J. Preparation of enzymatically recyclable hydrogels through the formation of inclusion complexes of amylose in a vine-twining polymerization. Chem. Asian J. 5, 1627-1633 (2010).

36 Yanase, M., Takata, H., Fujii, K., Takaha, T. \& Kuriki, T. Cumulative effect of amino acid replacements results in enhanced thermostability of potato type $\mathrm{L} \alpha$-glucan phosphorylase. Appl. Environ. Microbiol. 71, 5433-5439 (2005).

37 Fukuzaki, H., Yoshida, M., Asano, M., Aiba, Y. \& Kumakura, M. Direct copolymerization of glycolic acid with lactones in the absence of catalysts. Eur. Polym. J. 26, 457-461 (1990).
38 Barakat, I., Dubois, P., Grandfils, C. \& Jerome, R. Poly( $\varepsilon$-caprolactone-b-glycolide) and poly(D,L-lactide- $b$-glycolide) diblock copolyesters: Controlled synthesis, characterization, and colloidal dispersions. J. Polym. Sci. Part A: Polym. Chem. 39, 294-306 (2001).

39 Braunmühl, V. V., Jonas, G. \& Stadler, R. Enzymatic grafting of amylose from poly(dimethylsiloxanes). Macromolecules 28, 17-24 (1995).

40 Seneviratne, H. D. \& Biliaderis, C. G. Action of $\alpha$-amylases on amylose-lipid complex superstructures. J. Cereal. Sci. 13, 129-143 (1991).

41 Nuessli, J., Sigg, B., Conde-Petit, B. \& Escher, F. Characterization amylose-flavour complexes by DSC and X-ray diffraction. Food Hydrocolloids 11, 27-34 (1997).

42 Yamashita, Y. Single crystals of amylose V complexes. J. Polym. Sci. Part A 3 , 3251-3260 (1965)

43 Zobel, H. F., French, A. D. \& Hinkle, M. E. X-Ray diffraction of oriented amylose fibers. II. Structure of V amyloses. Biopolymers 5, 837-845 (1967)

44 Zobel, H. F. Starch crystal transformations and their industrial importance. Starch 40 , $1-7$ (1988).

45 Mayo, F. R. \& Lewis, F. M. Copolymerization. I. A basis for comparing the behavior of monomers in copolymerization; the copolymerization of styrene and methyl methacrylate. J. Am. Chem. Soc. 66, 1594-1601 (1944).

46 Ivanova, T., Svendsen, A., Verger, R. \& Panaiotov, I. Enzymatic hydrolysis by humicola lanuginosa lipase of poly(lactic acid)-poly(glycolic acid) monolayers. Colloid Polym. Sci. 278, 719-727 (2000). 